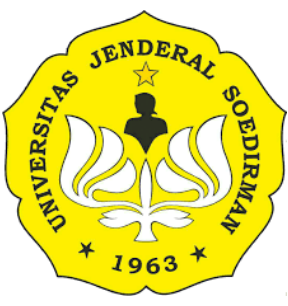

\author{
SOEDIRMAN ECONOMICS EDUCATION JOURNAL \\ http://jos.unsoed.ac.id/index.php/seej/
}

\title{
ANALISIS DAMPAK EKONOMI PENERAPAN PAPERLESS ADMINISTRATION PADA BIAYA OPERASIONAL DI SEKOLAH
}

\author{
Dwi Riyani Darma Setianingsih ${ }^{*}$, Abdul Wachid B.S. ${ }^{2}$ \\ ${ }^{1}$ Jurusan MPI, IAIN Purwokerto, Indonesia \\ ${ }^{2}$ IAIN Purwokerto, Indonesia \\ *Email corresponding author: dwiriyani68@gmail.com
}

\begin{abstract}
ABSTRAK
Pandemi covid-19 sangat berpengaruh terhadap pendidikan, khususnya di sekolah. Salah satu dampaknya adalah pada aspek administrasi sekolah. Penelitian ini bertujuan untuk menganalisis dampak ekonomi penerapan paperless administration sehingga dapat digunakan untuk pengambilan kebijakan di sekolah. Penelitian dilaksanakan pada tanggal 20 sampai dengan 25 Desember 2020. Penelitian ini menggunakan metode penelitian deskriptif kualitatif. Hasil penelitian menunjukan bahwa dampak ekonomi penerapan paperless administration pada operasional di sekolah sangat positif yaitu dari RKAS TP 2020/2021 yang direncanakan sebesar Rp 873.103.755,00 dijabarkan ke dalam RKA menjadi Rp 620.116.561,00 realisasinya menjadi Rp 555.393.206,00 atau $90 \%$, artinya terdapat penurunan biaya $10 \%$. Hasil analisis belanja cetak dan ATK penurunannya lebih besar lagi yaitu dari rencana anggaran sebesar Rp 58.858.300,00 hanya terserap Rp. 27.325.500,00 atau 46.34\%. Terjadi penurunan biaya sebesar $53.57 \%$. Efisiensi atas penerapan paperless administration berdampak positif pada program-program sekolah yang lain pada masa pandemi covid-19.
\end{abstract}

Kata Kunci: Dampak Ekonomi; Paperless Administration; Covid-19

The Covid-19 pandemic has a very strong impact on education, especially in schools. One of the impacts is on the aspects of school administration. This study aims to analyze the economic impact of the application of paperless administration so that it can be used for policy making in schools. The research was conducted on December 20 to 25 2020. This study used a qualitative descriptive research method. The results showed that the economic impact of the application of paperless administration on operations in schools was very positive, namely from the RKAS TP 2020/2021 which was planned for Rp. 873,103,755.00 translated into RKA to Rp. 620,116,561.00, the realization was Rp. 555,393,206.00 or $90 \%$, meaning that there is a $10 \%$ reduction in costs. The results of the analysis of print expenditure and stationery the decrease was even greater, namely from the planned budget of Rp. $58,858,300.00$ only Rp. $27,325,500.00$ or $46.34 \%$. There was a decrease in costs by $53.57 \%$. The efficiency of the application of paperless administration had a positive impact on other school programs during the Covid-19 pandemic.

Keywords: Economics Impact; Paperless Administration; Covid-19

\section{PENDAHULUAN}

Menurut Huang et al. (2020), virus corona, yang dikenal sebagai Covid-19, ditemukan pada bulan Desember tahun 2019, di pasar makanan laut di Wuhan. Pandemi COVID-19 memberikan dampak luar biasa pada segala aspek kehidupan, salah satunya adalah aspek Pendidikan. Pandemi Covid-19 telah 
mengakibatkan banyak sekolah tutup di seluruh dunia. Secara global, lebih dari 1,2 miliar anak di 186 negara yang terkena dampak penutupan sekolah karena pandemi. Penutupan sekolah secara fisik mendorong semua institusi pendidikan untuk bermigrasi ke platform online (Olasile, 2020). Pembelajaran online adalah penggunaan internet dan beberapa teknologi penting lainnya untuk mengembangkan materi untuk tujuan pendidikan, instruksional pengiriman dan pengelolaan program.

Hrastinski (2008) menyatakan bahwa terdapat dua jenis pembelajaran online, yaitu pembelajaran online asynchronous dan synchronous. Pelaksanaan pembelajaran online asinkronus yaitu seorang guru dapat menyiapkan materi lebih dulu, dan interaksi pembelajaran dilakukan secara fleksibel dan tidak harus dalam waktu yang sama, misalkan menggunakan forum diskusi atau belajar mandiri/penugasan siswa. Sedangkan pada pembelajaran sinkronus interaksi pembelajaran antara guru dan siswa dilakukan pada waktu yang bersamaan, menggunakan teknologi video conference atau chatting.

Pemberlakuan pembelajaran online memaksa guru untuk melek IT. Guru harus belajar tentang penggunaan teknologi informasi terutama untuk model-model pembelajaran jarak jauh. Dengan diberlakukannya pembelajaran jarak jauh, maka aktifitas pembelajaran sebagian besar dilakukan melalui online. Baik itu untuk tatap muka, penugasan, penilaian harian, penilaian tengah semester, penilaian akhir semester, sampai dengan Ujian Sekolah.

Dampak lain dari pelaksanaan pembelajaran secara online adalah pada aspek administrasi sekolah. Sekolah menerapkan paperless administration. Paperless adalah kebijakan pengurangan kertas dalam kegiatan administrasi. Paperless administration pada sistem pendidikan di sekolah salah satu contohnya ketika penugasan, ulangan harian, penilaian tengah semester, penilaian akhir semester, bahkan ujian sekolah tidak memerlukan kertas untuk mencetak soalnya. Soal didistribusikan dalam bentuk dokumen yang bersifat digital sehingga dapat dibuka di gawai masing-masing siswa. Berdasarkan fenomena tersebut, maka penulis tertarik untuk meneliti tentang dampak ekonomi penerapan paperless administration terhadap operasional sekolah. Harapannya hasil penelitian ini dapat dijadikan bahan pertimbangan dalam pengambilan kebijakan sekolah.

\section{TINJAUAN PUSTAKA}

\section{Biaya Operasional Sekolah}

Menurut Permendikbud Nomor 8 Tahun 2020, Biaya operasional sekolah (BOS) adalah program Pemerintah Pusat untuk penyediaan pendanaan biaya operasional bagi Sekolah yang bersumber dari dana alokasi khusus nonfisik. BOS merupakan penopang inti pembiayaan proses pendidikan di sekolah negeri maupun swasta. Penggunaanya berdasarkan Permendikbud Nomor 19 Tahun 2020. Biaya per peserta didik dari pemerintah untuk saat ini Rp. 1.000.000,00 untuk jenjang Sekolah Dasar (SD), Rp.1.200.000,00 untuk jenjang Sekolah Menengah Pertama (SMP), dan Rp.1.500.000,00 untuk jenjang Sekolah Menengah Atas (SMA). Dana tersebut benar-benar harus digunakan untuk proses pembelajaran dan peningkatan mutu pendidikan peserta didik. Untuk saat ini laporannya sudah melalui online, sehingga lebih transparan dan akuntabel. 
Dana BOS Reguler yang diterima oleh Sekolah digunakan untuk membiayai operasional penyelenggaraan pendidikan di Sekolah. Operasional penyelenggaran pendidikan di Sekolah dilaksanakan untuk membiayai: a) penerimaan Peserta Didik baru; b) pengembangan perpustakaan; c) kegiatan pembelajaran dan ekstrakurikuler; d) kegiatan asesmen/evaluasi pembelajaran; e) administrasi kegiatan sekolah; f) pengembangan profesi guru dan tenaga kependidikan; g) langganan daya dan jasa; h) pemeliharaan sarana dan prasarana Sekolah; i) penyediaan alat multimedia pembelajaran; j) penyelenggaraan bursa kerja khusus, praktik kerja industri atau praktik kerja lapangan di dalam negeri, pemantauan kebekerjaan, pemagangan guru, dan lembaga sertifikasi profesi pihak pertama; k) penyelenggaraan kegiatan uji kompetensi keahlian, sertifikasi kompetensi keahlian dan uji kompetensi kemampuan bahasa Inggris berstandar internasional dan bahasa asing lainnya bagi kelas akhir SMK atau SMALB; dan/atau l) pembayaran honor.

Di masa covid-19 ini, pemerintah menegaskan bahwa pemanfaatan biaya operasional sekolah harus diutamakan untuk kepentingan penanggulangan penyebaran dan pencegahan covid-19 di sekolah dan lingkungan sekitar. BOS juga dapat digunakan untuk meningkatkan kesejahteraan guru-guru honorer yang sudah terdata di Dapodik. Pembayaran honor hanya dapat digunakan paling banyak 50\% (lima puluh persen) dari keseluruhan jumlah alokasi dana BOS Reguler yang diterima oleh Sekolah. Kemendikbud mengharapkan laporan pemakaian dana BOS mampu menggambarkan keadaan penggunaan BOS yang riil dan seutuhnya.

Pembelanjaan dana BOS Reguler dilaksanakan melalui mekanisme pengadaan barang dan/atau jasa di Sekolah sesuai dengan ketentuan peraturan perundang-undangan. Tim BOS Sekolah tidak boleh menggunakan dana BOS Reguler untuk: a) disimpan dengan maksud dibungakan; b) dipinjamkan kepada pihak lain; c) membeli perangkat lunak untuk pelaporan keuangan dana BOS Reguler atau perangkat lunak lainnya yang sejenis; d) sewa aplikasi pendataan atau aplikasi penerimaan peserta didik baru dalam jaringan; e) membiayai kegiatan yang tidak menjadi prioritas Sekolah; f) membiayai kegiatan dengan mekanisme iuran; g) membeli pakaian, seragam, atau sepatu bagi guru atau Peserta Didik untuk kepentingan pribadi (bukan inventaris Sekolah); h) digunakan untuk pemeliharaan prasarana Sekolah dengan kategori kerusakan sedang dan berat; i) membangun gedung atau ruangan baru; j) membeli saham; k) membiayai kegiatan dalam rangka mengikuti pelatihan, sosialisasi, pendampingan terkait program BOS Reguler atau perpajakan program BOS Reguler yang diselenggarakan lembaga di luar dinas pendidikan provinsi, kabupaten/kota, dan/atau Kementerian; l) membiayai kegiatan yang telah dibiayai secara penuh dari sumber dana Pemerintah Pusat, Pemerintah Daerah, atau sumber lainnya; m) melakukan penyelewengan penggunaan dana BOS Reguler untuk kepentingan pribadi atau kelompok tertentu; dan/atau n) bertindak menjadi distributor atau pengecer pembelian buku kepada Peserta Didik di Sekolah yang bersangkutan.

Pembelajaran jarak jauh yang sebagian besar melakukan pembelajaran online, memberikan dampak terhadap penggunaan dana BOS. Sebagian besar penilaian dilakukan secara online, baik itu menggunakan 
google form, maupun office form. Dengan demikian otomatis mengurangi biaya cetak soal penilaian tengah semester, penilaian akhir semester dan ujian sekolah.

\section{Administrasi Pendidikan}

Administrasi dalam arti sempit adalah mencatat setiap komponen administrasi yang meliputi komponen manajemen, organisasi, maupun kegiatan operasional (Nawawi, 2009). Administrasi pendidikan menurut Ngalim Purwanto (2010) adalah suatu kegiatan atau usaha untuk membantu, melayani, mengarahkan, atau mengatur semua kegiatan di dalam mencapai suatu tujuan. Oteng Sutisna dalam Suharsaputra (2013) menyoroti administrasi pendidikan dalam tiga bidang perhatian dan kepentingan yaitu: 1) setting administrasi pendidikan (geografi, demografi, ekonomi, ideologi, kebudayaan, dan pembangunan); 2) Pendidikan (bidang garapan adminiistrasi); dan 3) Substansi administrasi pendidikan (tugas-tugasnya, prosesnya, asas-asanya, dan perilaku administrasi). Administrasi Pendidikan adalah sebuah proses kerja sama untuk mencapai tujuan pendidikan dengan melihat hubungan antar komponen pendidikan sehingga dapat memperbaiki sistem pendidikan dengan menggunakan perangkat yang mendukung kegiatan pembelajaran. Tujuan administrasi pendidikan adalah untuk mencapai tujuan dari pendidikan tersebut atau sebagai alat untuk mencapai tujuan pendidikan. Terdapat 4 (empat) tujuan administrasi, yaitu: 1) Efektivitas produksi; 2) Efisiensi; 3) Kemampuan menyesuaikan diri; dan 4) Kepuasan Kerja.

Masa pandemi covid-10 memaksa lembaga pendidikan untuk melakukan pembelajaran jarak jauh, baik itu secara daring ataupun secara luring. Untuk sekolah-sekolah dasar yang jumlah muridnya sedikit dan kondisi wilayahnya sangat tidak memungkinkan untuk pembelajarn online maka masih bisa diatasi dengan cara pembelajaran luring, namun butuh pengorbanan guru-gurunya yang harus mendatangi rumah-rumah peserta didik. Hal seperti ini sangat jarang dilakukan. Namun bagi Sekolah Menengah Pertama (SMP) yang jumlah muridnya sekitar 32 per rombongan belajar hal tersebut sangat tidak memungkinkan. Mau tidak mau guru harus melakukan pembelajaran online.

Pembelajaran jarak jauh berdampak pula terhadap administrasi di sekolah yang juga secara otomatis banyak menggunakan adminsitrasi online, sehingga mengurangi biaya operasional administrasi sekolah. Administrasi sekolah bergeser dari penggunaan kertas secara menyeluruh menjadi paperless administration khususnya pada evaluasi pembelajaran.

\section{Paperless Administration}

Administrasi dengan menggunakan kertas merupakan suatu hal yang tidak efisien, membutuhkan biaya besar, dan memiliki resiko keamanan (Selvi, Khan, Rani, Prasad, Paul, \& Biswal, 2011). Salah satu solusi untuk mengatasi permasalahan tersebut adalah dengan paperless administration. Paperless merupakan suatu sistem yang diciptakan untuk mengelola sistem administrasi. Paperless administration memberikan kemudahan dalam berbagi dokumen dan mengambil dokumen (Welsh, 2007). Paperless 
memberikan banyak manfaat bagi organisasi dibandingkan dengan administrasi berbasis kertas, keuntungan tersebut antara lain: a) aksesibilitas file dan berbagi informasi yang lebih baik; b) penggunaan ruang penyimpanan fisik yang lebih sedikit; dan c) peningkatan produktivitas karena karyawan tidak perlu melakukan mencari dokumen (Stratton, 2013). Manfaat yang diberikan adanya paperless system menurut Lutteroth (2011) antara lain keamanan yang lebih baik, akses file yang lebih mudah, dan proses yang lebih efisien dan hemat biaya.

Dalam menerapkan paperless administration terdapat beberapa hal yang perlu diperhatikan oleh pengambil kebijakan antara lain: 1) Aspek Sumber Daya Manusia (Pengguna), dalam hal ini pengguna perlu diberikan pengetahuan mengenai cara penggunaan dokumen dan pendistribusian dokumen; 2) Aspek Dokumen, pada tahap awal penerapan dimulai pada jenis dokumen yang tidak sering didistribusikan, dan dibuat sistem dobel yakni offline dan online, dimana sistem Online akan secara penuh diberlakukan setelah dipastikan setiap individu pada level tertentu sudah dapat membuka dan membaca dokumen online; 3) Aspek Sistem Aplikasi, dokumen online disimpan dalam aplikasi yang terproteksi, berjenjang hak aksesnya serta mudah dalam pemakaiannya; 4) Aspek Sosialisasi, Individu yang memiliki hak akses tertentu dilatih untuk mengakses sistem agar dapat melakukan berbagai aktifitas sesuai fasilitas dalam sistem; 5) Aspek Sarana Pendukung, ketersediaan sarana perlu disediakan secukupnya, antara lain, tidak terbatas pada : Kebijakan, Hardware, Infrastruktur Jaringan, SDM tenaga bantu, dana, dan Forum komunikasi, dan lain-lain; dan 6) Aspek Komunikasi, penerapan kebijakan paperless administration memerlukan seorang visioner untuk dapat menjelaskan kenapa paperless administration diberlakukan dan diawali dengan penyampaian dan persaman persepsi dan tujuan. Pandemi covid-19 mendorong lembaga pendidikan untuk menerapkan paperless administration sehingga pembelajaran dapat tetap berjalan lancar sekaligus dapat mengurangi biaya pendidikan khususnya pada kegiatan belajar mengaajar.

\section{METODE PENELITIAN}

Penelitian ini menggunakan metode deskriptif kualitatif. Menurut Mukhtar (2013: 10) metode penelitian deskriptif kualitatif adalah sebuah metode yang digunakan peneliti untuk menemukan pengetahuan atau teori terhadap penelitian pada satu waktu tertentu. Melalui metode ini mencoba mengungkapkan bagaimana dampak ekonomi penggunaan administrasi online pada operasional di sekolah. Penelitian ini dilakukan di SMP Negeri 4 Banyumas. Penelitian dilaksanakan pada tanggal 20 sd. 25 Desember 2020.

\section{Teknik pengumpulan data}

Teknik yang digunakan untuk mengumpulkan data pada penelitian ini menggunakan studi dokumentasi, wawancara, dan observasi. Studi dokumentasi meliputi dokumen: 1) RKAS TP 2020/2021 dengan RKA BOS 2020; 2) hasil laporan realisasi RKAS BOS tahun 2020 SMP Negeri 4 Banyumas; 3) laporan penggunaan dana BOS 2020 tahun 2020 SMP Negeri 4 Banyumas; 4) laporan penggunaan dana BOS 
2020; dan 5) data realisasi belanja cetak dan ATK kegiatan PJJ masa covid-19 tahun 2020 SMP Negeri 4 Banyumas. Data realisasi anggaran belanja BOS berisi kegiatan dan pelaksanaan program-program 8 standar seperti yang telah direncanakan di RKAS. Wawancara dilakukan untuk mendapatkan data dari sumbernya langsung, sehingga peneliti mendapatkan penjelasan-penjelasan dan laporan yang bisa dipertanggungjawabkan. Wawancara tersebut dilakukan terhadap bendahara BOS SMP Negeri 4 Banyumas yang bernama Jumirah.

\section{Teknik Analisa Data}

Teknik analisis data yang digunakan dalam penelitian ini memiliki empat tahap yaitu pengumpulan data, reduksi data, penyajian data dan langkah terakhir adalah penarikan kesimpulan dan verifikasi. Data kualitatif berupa hasil studi dokumentasi dan wawancara. Untuk menjamin validitas data maka dilakukan triangulasi sumber data. Triangulasi sumber data adalah menggali kebenaran informai tertentu melalui berbagai metode dan sumber perolehan data. Misalnya, selain melalui wawancara dan observasi, peneliti bisa menggunakan observasi terlibat (participant obervation), dokumen tertulis, arsif, dokumen sejarah, catatan resmi, catatan atau tulisan pribadi dan gambar atau foto. Setelah data terkumpul maka langkah selanjutnya adalah reduksi data. Reduksi data merupakan penyederhanaan, penggolongan, dan membuang yang tidak perlu data sedemikian rupa sehingga data tersebut dapat menghasilkan informasi yang bermakna dan memudahkan dalam penarikan kesimpulan. Banyaknya jumlah data dan kompleksnya data, diperlukan analisis data melalui tahap reduksi. Tahap reduksi ini dilakukan untuk pemilihan relevan atau tidaknya data dengan tujuan akhir. Setelah melakukan reduksi data, selanjutnya data disajikan dan ditarik kesimpulan serta verifikasi atas kesimpulan tersebut.

\section{HASIL DAN PEMBAHASAN}

Pandemi covid-19 sangat berpengaruh terhadap pendidikan, khususnya di sekolah. Namun, ternyata dampak itu tidak selalu negatif, karena bila kita evaluasi, banyak juga dampak positifnya. Dampak positif yang nyata bisa kita lihat adalah guru-guru jadi melek IT. Mau tidak mau guru harus belajar tentang penggunaan IT terutama untuk model-model pembelajaran jarak jauh. Dengan diberlakukanya pembelajaran jarak jauh, maka aktifitas pembelajaran sebagian besar dilakukan melalui online. Baik itu untuk tatap mukanya, penugasan, penilaian harian, penilaian tengah semester, penilaian akhir semester, sampai dengan Ujian sekolah. Dampak positif yang bisa kita rasakan dengan pembelajran jarak jauh ini adalah berkurangnya penggunaan kertas, yang otomatis mengurangi biaya operasional sekolah. Dari permasalahan di atas, penulis ingin meneliti seberapa banyak berkurangnya biaya operasional sekolah dengan dilakukanya pembelajaran jarak jauh ini, dengan judul "Anaslisis Dampak Ekonomi Penggunaan Administrasi Online Pada Operasional di Sekolah".

Penelitian diawali dengan observasi/mengamati laporan penggunaan dana BOS tahun 2020 SMP Negeri 4 Banyumas. Kemudaian agar data bisa didapat lebih valid, penulis mewawancari bendahara BOS 
SMP Negeri 4 Banyumas yang bernama Ibu Jumirah. Bendahara menyampaikan bahwa SMP Negeri 4 Banyumas telah mengelola dana BOS sesuai dengan Juknis BOS semasa covid-19 seperti yang tertuang pada Permendikbud No 19 dan No 20 Tahun 2020. Menurut juknis tersebut penggunaan dana BOS dimasa covid lebih banyak dialokasikan untuk kebutuhan membantu menambah honor guru honorer dan untuk pencegahan covid-19 misalnya untuk membrikan banuan masker kepada peserta didik, guru dan karyawan, penyemprotan disinfektan, pembelian alat pengukur suhu, tempat cuci tangan, dan handsanitizer. Menurut Muradi:2020, Katman menjelaskan, pemanfaatan dana BOS di masa pandemi Covid tercantum di dalam SE-4 Mendikbud/2020. Selain itu, ada pula relaksasi sesuai dengan Permendikbud 19/2020 yang memperbolehkan pembelian disifektan, alat cuci tangan, dan sebagainya menggunakan BOS.

Dari wawancara dengan bendahara BOS,Ibu Jumirah, diperoleh penjelasan-penjelasan tentang: 1) Realisasi RKAS BOS tahun 2020; 2) Laporan Penggunaan Dana BOS 2020 SMP Negeri 4 Banyumas; 3) Data Realisasi Belanja Cetak dan ATK Kegiatan PJJ Masa Covid-19 Tahun 2020 SMP Negeri 4 Banyumas. Dari data di atas diketahui bahwa prosentase penyerapan dana dari 8 standar tidak maksimal. Hal itu tidak berarti bahwa dana tidak digunakan secara maksimal, namun karena memang sesuai juknis, ada kegiatan-kegiatan di masa pandemic covid -19 yang tidak bisa dilaksanakan dan yang lebih utama karena banyak kegiatan yang dilakukan secara on line. Berikut ini penulis sampaikan laporan secara rinci tentang realisasi RKAS BOS tahun 2020 SMP Negeri 4 Banyumas:

Tabel 1. Laporan Realisasi RKAS BOS Tahun 2020

\begin{tabular}{|c|c|c|c|c|c|}
\hline \multirow[t]{3}{*}{ NO } & \multirow[t]{3}{*}{ URAIAN } & \multicolumn{4}{|c|}{ DATA REALISASI ANGGARAN BELANJA BOS } \\
\hline & & RKAS & RKA BOS & Realisasi & Persentase \\
\hline & & ТР.2020/2021 & 2020 & & \\
\hline 1. & $\begin{array}{l}\text { Pengembangan Kompetensi } \\
\text { Lulusan }\end{array}$ & 27.022 .100 & 17.564 .365 & 11.883 .500 & $68 \%$ \\
\hline 2. & Pengembangan tandar Isi & 20.709 .800 & 18.638 .820 & 18.403 .500 & $99 \%$ \\
\hline 3. & $\begin{array}{l}\text { Pengembangan Standar } \\
\text { Proses }\end{array}$ & 234.835 .555 & 129.159 .555 & 78.102 .100 & $60 \%$ \\
\hline 4. & Pengembangan PTK & 25.250 .000 & 12.625 .000 & 11.568 .000 & $92 \%$ \\
\hline 5. & Pengembangan Sarpras & 205.781 .800 & 156.336 .350 & 152.541 .300 & $98 \%$ \\
\hline 6. & $\begin{array}{l}\text { Pengembangan Standar } \\
\text { Pengelolaan }\end{array}$ & 21.953 .000 & 16.025 .690 & 15.786 .000 & $99 \%$ \\
\hline 7. & $\begin{array}{l}\text { Pengembangan Standar } \\
\text { Pembiayaan }\end{array}$ & 268.946 .500 & 228.603 .781 & 228.334 .306 & $100 \%$ \\
\hline 8. & $\begin{array}{l}\text { Pengembangan dan } \\
\text { Implementasi sistem } \\
\text { Penilaian }\end{array}$ & 68.605 .000 & 41.163 .000 & 38.774 .500 & $94 \%$ \\
\hline 9. & JUMLAH & 873.103 .755 & 0.116 .561 & 5.393 .206 & $90 \%$ \\
\hline
\end{tabular}

Berdasarkan Tabel 1 dapat dicermati bahwa persentase keterserapan administrasi pengembangan kompetensi lulusan hanya $68 \%$, hal tersebut dikarenakan ujian nasional ditunda, sehingga pembiayaan 
persiapan dan pelaksanaan ujian nasional dihilangkan. Sedangkan pelaksanaan Ujian Sekolah dan Ujian Praktek dilakukan secara on line, sehingga biaya cetak soal juga berkurang. Persentase keterserapan administrasi pengembangan Standar Isi mencapai 99\%. Hal tersebut dikarenakan untuk Standar Isi tidak banyak perubahan dengan kondisi normal.

Keterserapan administrasi Standar Proses mencapai 60\%. Standar proses memiliki persentase tingkat keterserapan paling rendah karena dampak dari pembelajaran jarak jauh yang dilakukan secara online. ATK yang berkenaan dengan pembelajaran di kelas secara otomatis berkurang banyak. Persentase keterserapan administrasi pengembangan PTK 92\%. Terlihat masih banyak karena pelaksanaan IHT tetap dilaksanakan meskipun secara online. Sekolah memberikan bantuan pulsa kepada guru untuk mendukung kegiatan tersebut.

Persentase keterserapan administrasi pengembangan Pengelolaan 98\%. Termasuk tinggi karena banyak untuk pembelian alat-alat yang berkenaan dengan penanggulangan covid-19 dan juga untuk biaya perawatan barang. Persentase keterserapan administrasi pengembangan pengelolaan 99\%. Tidak banyak berkurang karena pelaksanaan kegiatan masih hampir sama dengan dimasa normal. Persentase keterserapan administrasi pengembangan pembiayaan tidak berubah, dan masih sama dengan dikondisi normal. Persentase keterserapan administrasi pengembangan dan Implementasi Sistem Penilaian 94\%. Hal itu dikarenakan kegiatan penilaian tengah semester, penilaian akhir semester, penilaian ujian sekolah dan ujian praktek dilaksanakan secara online, sehingga mengurangi biaya cetak.

Untuk melengkapi data agar lebih jelas terlihat dampak ekonomi penggunaan administrasi online pada operasional di sekolah, berikut ini penulis sajikan data realisasi belanja cetak dan ATK kegiatan PJJ masa Covid-19 tahun 2020 SMP Negeri 4 Banyumas.

Tabel 2. Data Realisasi Belanja Cetak dan ATK Kegitan PJJ di masa pandemi Covid-19 Tahun 2020 SMP Negeri 4 Banyumas

\begin{tabular}{cllll}
\hline NO & RINCIAN BELANJA & ANGGARAN & REALISASI & PROSENTASE \\
\hline 1. & Belanja Cetak & 38.152 .500 & 10.144 .500 & $26.59 \%$ \\
\hline 2. & Belanja ATK & 20.705 .800 & 17.181 .000 & 82.98 \\
\hline & JUMLAH & 58.858 .300 & 27.325 .500 & $46.43 \%$ \\
\hline
\end{tabular}

Dari hasil analisis data-data di atas bisa disimpulkan bahwa ternyata dampak ekonomi penggunaan administrasi online pada operasional di sekolah pada masa pandemi covid-19 ini sangat postif. Hal tersebut dibuktikan bahwa penyerapan dana hampir di semua standar berkurang, kecuali untuk Standar Pembiayaan yang tetap terserap 100\%. Untuk lebih jelasnya seberapa banyak berkurangnya dana untuk tiap standar dapat dirlihat pada rincian berikut: 1) Pengembangan Kompetensi Lulusan terjadi penurunan biaya 32\%; 2) Pengembangan Standar Isi penggunaan dana berkurang $1 \%$; 3) Pengembangan Standar Proses berkurang 40\%; 4) Pengembangan PTK berkurang 8\%; 5) Pengembangan Sarpras berkurang 2\%; 6) Pengembangan Standar Pengelolaan berkurang 1\%; 7) 
Pengembangan dan Implementasi Sistem Penilaian berkurang 6\%. Dari semua standar pengembangan di atas setelah dijumlah maka diketahui penurunan penggunaan dana di masa covid-19 mencapai 10\%.

Di standar penilaian terlihat bahwa penurunan biaya administrasi hanya $6 \%$, hal tersebut dikarenakan guru tetap harus membuat administrasi offline sebagai bukti pertanggungjawaban pelaksanaan perencanaan dan pelaksanaan pembelajaran. Namun jika kita lihat data realisasi belanja cetak dan ATK kegiatan PJJ masa covid-19 tahun 2020 SMP Negeri 4 Banyumas sangat terlihat penurunan biaya yang sangat signifikan, yaitu hanya $46,43 \%$ dari rencana anggaran. Hasil penelitian menunjukan bahwa dampak ekonomi penggunaan administrasi online pada operasional di sekolah sangat positif yaitu dari RKAS TP 2020/2021 yang direncanakan sebesar Rp 873.103.755,00 dijabarkan ke dalam RKA menjadi Rp 620.116.561,00 realisasinya menjadi Rp 555.393.206,00 atau 90\%. Ada penurunan biaya 10\%. Hasil analisis belanja cetak dan ATK penurunanya lebih banyak lagi yaitu dari rencana anggaran sebesar Rp 58.858.300,00 hanya terserap Rp 27.325.500,00 atau 46,34\%. Terjadi penurunan biaya sebesar 53,57\%. Berdasarkan hal tersebut maka dapat diketahui bahwa efisiensi atas penerapan paperless administration yang sudah dilakukan di SMP Negeri 4 Banyumas sejalan dengan hasil penelitian Lutteroth (2011) yang menyatakan bahwa paperless memberikan keamanan yang lebih baik, akses file yang lebih mudah, proses yang lebih efisien dan hemat biaya.

\section{KESIMPULAN}

Hasil analisis dampak ekonomi penggunaan administrasi online pada operasional di sekolah di SMP Negeri 4 Banyumas menunjukkan bahwa dampak ekonomi penggunaan administrasi online pada operasional di sekolah sangat positif yaitu dari RKAS TP 2020/2021 yang direncanakan sebesar Rp 873.103.755,00 dijabarkan ke dalam RKA menjadi Rp 620.116.561,00 realisasinya menjadi Rp 555.393.206,00 atau 90\% artinya terjadi penurunan biaya 10\%. Hasil analisis belanja cetak dan ATK penurunanya lebih banyak lagi yaitu dari rencana anggaran sebesar Rp 58.858.300,00 hanya terserap Rp 27.325.500,00 atau 46,34\%. Terjadi penurunan biaya sebesar 53,57\%.

\section{DAFTAR PUSTAKA}

Hrastinski, S. 2008. Asynchronous and synchronous e-learning. Educause Quarterly, 31(4), 51-55

Huang, C., Wang, Y., Li, X., Ren, L., Zhao, J., Hu, Y., Zhang, L., Fan, G., Xu, J., Gu, X., \& Cheng, Z. 2020. Clinical features of patients infected with 2019 novel coronavirus in Wuhan, China. The Lancet, 395(10223), 497-506. https://doi.org/10. 1016/S0140-6736(20)30183-5

Lutteroth, C. \& Weber, G. (2011). Going paperless - on the evaluation of electronic form technologies." In 2012 23rd International Workshop on Database and Expert Systems Applications. IEEE Computer Society, 14-18. http://doi.ieeecomputersociety.org/10.1109/DEXA.2011.38

Nawawi. 2009. Nawawi, Ismail, 2009. Perilaku Administrasi, Kajian Paradigma, Konsep, Teori dan Pengantar Praktik. Surabaya: ITS Press. 
Olasile Babatunde Adedoyin \& Emrah Soykan. 2020. Covid-19 pandemic and online learning: the challenges and opportunities. Interactive Learning Environments. DOI: 10.1080/10494820.2020.1813180

Purwanto, Ngalim. 2010. Administrasi dan Supervisi Pendidikan. Bandung: PT Remaja Posdakarya.

Selvi, S., Khan, S., Rani, U., Prasad, B. N., Paul, A. K., \& Biswal, A. K. (2011). Document management system-go green 'a paperless office' for steel plants. Steel Times International, 35(8), 39-41

Welsh, T. (2007, December). Growing profits with technology. Journal of Financial Planning, 20, 11. http://connection.ebscohost.com/c/articles/27518324/growing-profits-technology 